
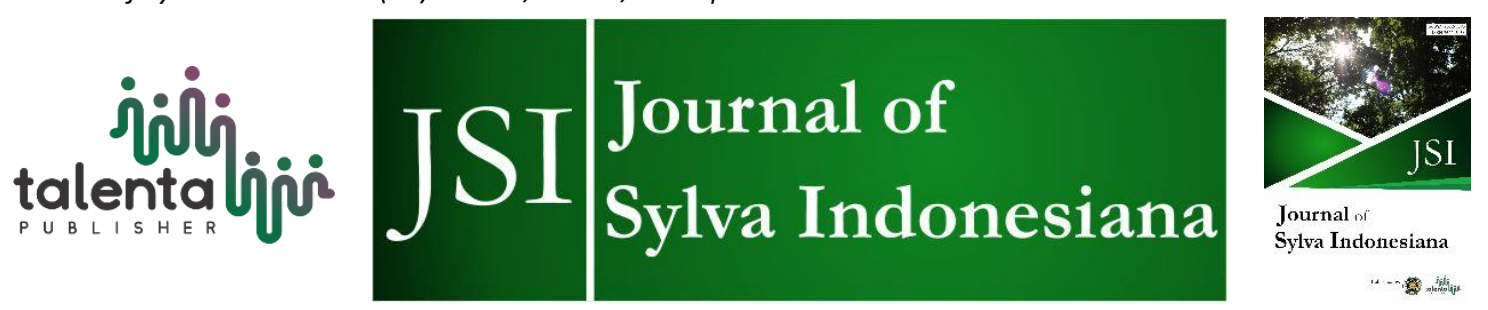

\title{
Mapping Land Cover and Vegetation Detection in Urban Areas
}

\author{
Anita Zaitunah $^{1,2}$, Samsuri ${ }^{1,2 *}$, Anggie Yohanna Mandalahi, and Lailan \\ Syaufina ${ }^{3}$
}

${ }^{1}$ Forest Management Department, Faculty of Forestry, Universitas Sumatera Utara, Jalan Tri Darma Ujung No 1 Medan 20155, North Sumatra, Indonesia

${ }^{2}$ JATI - Sumatran Forestry Analysis Study Center, Jalan Tri Dharma Ujung No 1 Medan 20155, North

Sumatra, Indonesia

${ }^{3}$ Department of Silviculture, Faculty of Forestry, IPB University (Bogor Agricultural University), Bogor, Indonesia

\begin{abstract}
The increase in population has caused land use change. The development of a city has increased the need for settlements and buildings. Monitoring any land cover is essential to support environmentally based and sustainable urban planning. Medan, as one of the big cities in Indonesia, has shown development of the areas. The study aims to analyze the land cover and vegetation existence in two sub-districts of Medan. The supervised classification analysis was conducted for the year 2019. A ground check was a part of the study. There were six land cover classes found in the area: paddy fields, grass, shrubs, trees, mixed plant, and built-up land. The largest area within two sub-districts was the built-up land. The result showed that the vegetated areas within two sub-districts were fewer. There was $86 \%$ of built-up land in Medan Baru and $69.3 \%$ in Medan Selayang. Vegetation is a critical element in the urban environment. There is a need to plant trees in less vegetated areas. Green open space should be incorporated into city planning to preserve and improve the quality of the urban environment.
\end{abstract}

Keyword: Land cover, Medan, Remote Sensing, Urban, Vegetation

Received 6 September 2021 | Revised 25 November 2021 | Accepted 30 November 2021

\section{Introduction}

A dense population and developed areas are within the characteristics of a city. Changes in land cover over time are prominent in a city's development. As mentioned by [1] cities as habitat mosaics in small spatial scales change through time. The development has caused the expansion of built-up areas, such as settlements and buildings. A compact vegetated land has changed into complex land cover by different uses. Environment heterogeneity was existed in cities due to

\footnotetext{
*Corresponding author at: Forest Management Department, Faculty of Forestry, Universitas Sumatera Utara, Jalan Tri Darma Ujung No 1 Medan 20155, North Sumatra, Indonesia

E-mail address: samsuri@usu.ac.id 
the variation within. As stated by [2], among other land surface features, the most heterogeneous landscape was the urban landscape.

The increasing population was one of the factors that led to urban area change [3]. People need land for residential and economic purposes. As stated by [1], urbanization entails numerous interacting elements of environmental change. The rapid urbanization resulted in the transition of the land cover into built-up regions [4], therefore having a significant contribution to changes [5]-[6]. Many urban studies deal with the expansion and its relation to land cover change. Those studies include urban ecology [1], urban sprawl [7]-[9], urban expansion pattern [10], trends in expansion, density, and transition [11]. Furthermore, [11] also stated that landscapes and livelihoods are affected by urban area expansion. Some of the main issues in urban are climate change [12]-[15] and environmental pollution [16]-[22]. Monitoring, as the control function of growth and development of the urban area [3], is a necessary input to urban planning. For instance, the insufficiency of urban expansion data hindered the effectiveness of land use planning [5]. It is related to how the city planner considers the environmental quality in their development plan, including the need for green open space. Particularly in developing countries, there was a shift of rural to the urban population [23]. Urban planning and management become critical in achieving sustainable development goals (SDGs) [24]. Analysis of urban sustainability is a key to the planning [25], and it needs the monitoring of urban compositions spatially and temporally. Furthermore, they can be extracted using remote sensing as widely applied [3], [26].

Remote sensing and geographic information technologies can support the data and information statistically and spatially. A study of [5] analyzes the urban land cover change to support land use planning using the multi-temporal Landsat images to explore changes [5]-[6].

Remote sensing has been used in many research including urban areas. The technology has proved to support analysis on land cover and land use detection and monitoring. According to [27] stated that remote satellite technologies, as the technique to monitor the urban area [3], have approved their ability by giving accurate and appropriate information on land use distribution. Medan Baru and Medan Selayang are developed areas within Medan city with various socioeconomic activities. Information on the vegetation and the land cover types can be used as guidance for integrated urban planning, especially in both sub-districts.

\section{Research Method}

\subsection{Study area}

The research was carried out between December 2019 and April 2020, in Medan Baru and Medan Selayang sub-districts, Medan, North Sumatra (Figure 1). Medan is the capital city of North Sumatra. It lies in $3^{\circ} 30^{\prime}-3^{\circ} 43^{\prime} \mathrm{N}$ and $98^{\circ} 35^{\prime}-98^{\circ} 44^{\prime} \mathrm{E}$. The analysis was done in Universitas Sumatera Utara. 

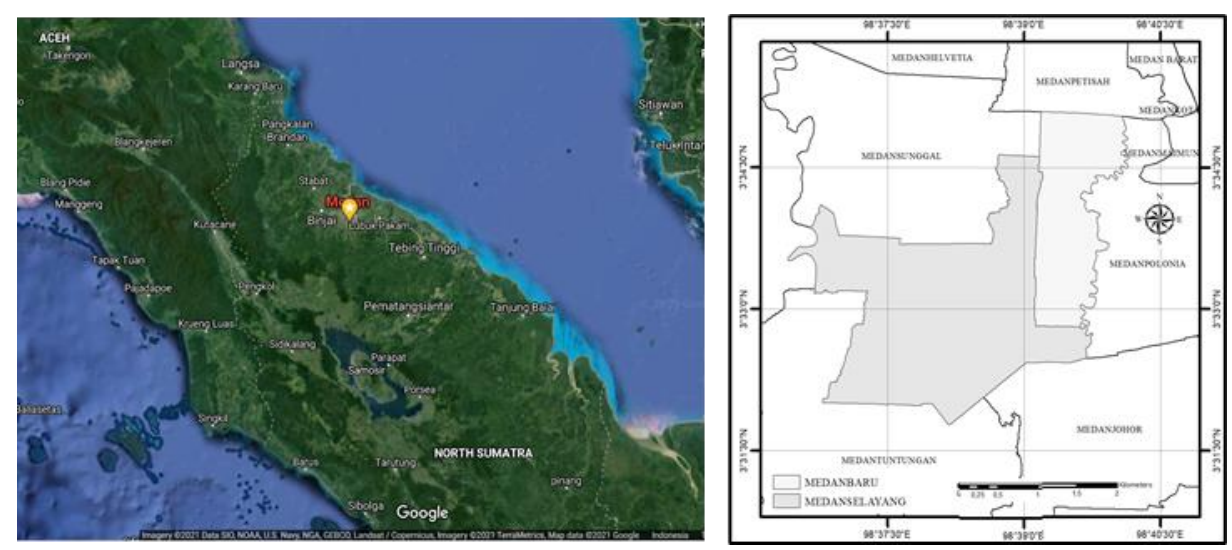

Figure 1 Research location

\subsection{Data preparation}

The satellite data of Landsat image 8 Operational Land Imager (OLI) (the year 2019) was downloaded from the earth explorer of The United States Geological Survey (USGS). An administration map of Medan was used to specify the study areas. Ancillary data (ground check data of land cover) was recorded using Global Positioning System. High-resolution images via Google Earth were used to give additional information on specific areas.

\subsection{Land use land cover classification}

ERDAS Imagine 9.1 was used for image processing. Layer stacking was applied to get a single layer. The research area was obtained by clipping the image using an administration map of Medan in ArcGIS 10.3. The maximum likelihood algorithm was used for this classification. Thus, in some mixed heterogeneous pixels, signatures had input from Google Earth which has higher resolutions satellite images. During the classification, image processing recognized the pixels which have similar spectral properties. It was done as a representation of each specific feature found [28]. Accuracy assessment was conducted to evaluate how the classification represents the real world [29], [3]. The overall accuracies of the maps that ranged between $84 \%$ - 95.7\%, were considered for land cover map production [23].

Generally, the urban areas were classified into vegetated areas and built-up areas. For detailed information, it was divided into six classes, i.e., paddy fields, trees, grass, mixed plants, shrubs, and built-up areas. Mixed plants were the term for heterogeneous vegetation, mainly crops. The built-up areas were the areas of settlements and buildings. The land cover difference depends on the specific condition of the urban areas. Some researches have divided urban areas into some classes such as vegetated areas, built-up areas, agricultural, bare, and scrublands [23]; bare land, built-up area, vegetation and water [30]; or bare soil with low vegetation density, built-up, vegetation, and water body [3]. 


\section{Results and Discussion}

\subsection{Land cover types of Medan Sub-districts}

Remote sensing and GIS allow conducting land cover detection and change analysis. Satellite images, including Landsat, have been widely used in urban studies [31]-[34], [6]. Many researchers studied land use land cover (LULC) using these technology [35], [29], [5], [36][39]. Land use and land cover could be monitored and predicted using remote sensing and GIS [40]. Also, there are many urban studies such as land surface temperature changes [2], [27], urban land cover change modeling [41], population density modeling [42], subpixel land-cover classification [43]-[44], and the study of various indices for extraction Urban Impervious Surface [45].

Within the area of $30 \mathrm{~m}$ as the spatial resolution of the Landsat image, there are many objects that existed in urban areas. So, it could contribute to an error in classification results. It was mentioned by [46] that the land use in urban areas is diverse and complex. There are difficulties in identifying land use and functional areas due to different definitions of similar built-up features. The ground check data can describe the objects within the areas. It was hard to find a homogenous object with big areas in urban. Most of the areas are diverse and complex, for example, houses with some trees around. The result of classification can be seen in Figure 2 and Figure 3. In both Medan sub-districts, the built-up is the largest area. The green areas are found in some places but not in large or homogeneous patterns.
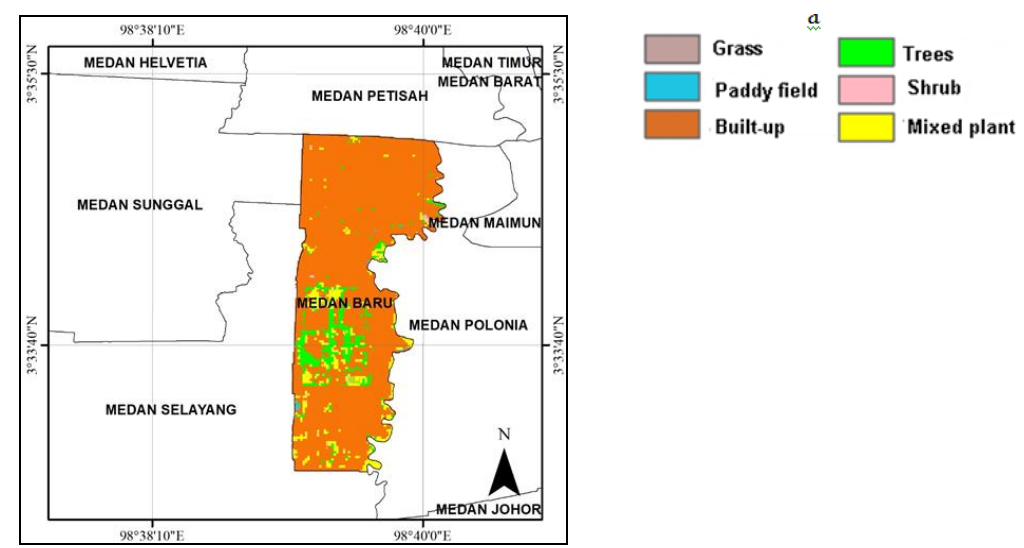

Figure 2 Land cover of Medan Baru of year 2019
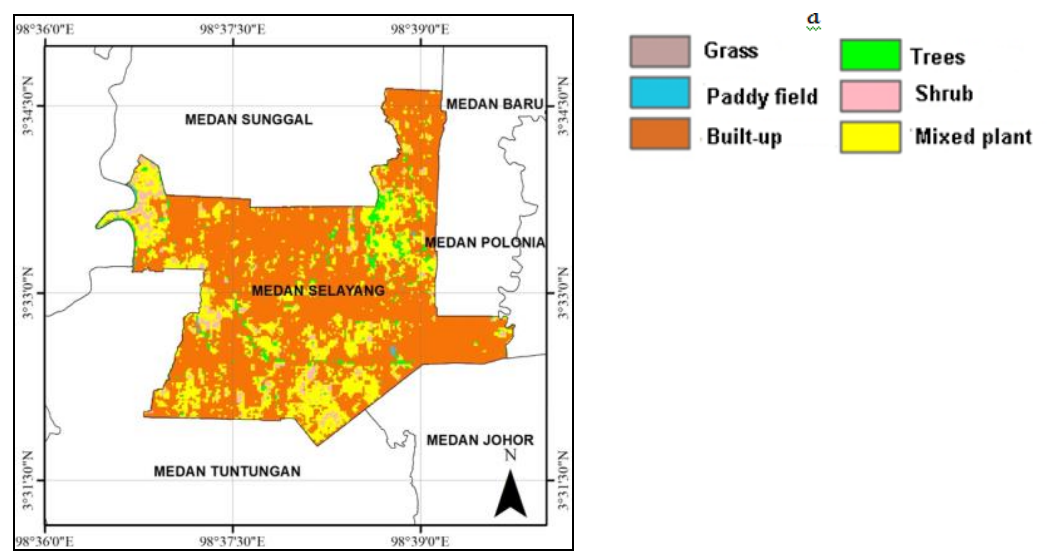

Figure 3 Land cover of Medan Selayang of year 2019 
It was found that $86 \%$ of Medan Baru was built-up areas in 2019. Table 1 illustrates the distribution of land cover in Medan Baru.

Table 1 Area of land use land cover in Medan Baru

\begin{tabular}{lcc}
\hline \multirow{2}{*}{ Land cover } & \multicolumn{2}{c}{ Year 2019 } \\
\cline { 2 - 3 } & Areas (Ha) & $\%$ \\
\hline Paddy field & 1,0 & 0,2 \\
Trees & 33,4 & 6,1 \\
Grass & 1,5 & 0,3 \\
Mixed plants & 38,9 & 7,1 \\
Shrub & 2,1 & 0,4 \\
Built-up land & 473,6 & 86,0 \\
\hline Total & 550,5 & 100 \\
\hline
\end{tabular}

A different situation is found in Medan Selayang, which has the larger vegetated land in 2019 compared to Medan Baru. Medan Selayang is also dominated by built-up land, 69.3\% of the total area. Table 2 illustrates the distribution of land cover in Medan Selayang.

Table 2 Areas of land use land cover in Medan Selayang

\begin{tabular}{lcc}
\hline \multirow{2}{*}{ Land cover } & \multicolumn{2}{c}{ Year 2019 } \\
\cline { 2 - 3 } & Areas $(\mathrm{Ha})$ & $\%$ \\
\hline Paddy field & 4.5 & 0.3 \\
Trees & 39.3 & 2.7 \\
Grass & 0.3 & 0.02 \\
Mixed plants & 355.8 & 24.0 \\
Shrub & 54.7 & 3.7 \\
Built-up areas & $1,028.5$ & 69.3 \\
\hline Total & $1,483.1$ & 100.0 \\
\hline
\end{tabular}

Changes in ecosystem patterns could be led by the change of land cover. The change of vegetated land into built-up areas will be harmful to the quality of the environment, especially with the increase of pollution by vehicles and industries. It could also affect the drinking water supply, as mentioned by [47], [53].

\subsection{Vegetation existence in urban area of Medan}

The high population density in Medan affects the high level of pollution and emissions due to a large number of vehicles. The existence of a green open space area could be one of the efforts to reduce emissions and air pollution that occurs in the city of Medan. In Medan Baru and Medan Selayang, there are 27 tree species found in the green open spaces and those on the roadside i.e. Swietenia mahagoni, Tamarindus indica, Mimusops elengi, Gmelina arborea, Ceiba pentandra, Ficus benjamina, Paraserianthes falcataria, Polyalthia longifolia, etc.

In some parts, communities use the land for planting mixed crops, for instance, Zea mays, Saccharum officinarum, Manihot utilissima, and Cocos nucifera. There were also some fruit 
trees and oil palm found in the area. Trees are required to encounter the carbon dioxide emitted by vehicles and industries. Green space in the public area is regarded as a public good. The local municipality is responsible for providing a suitable amount and the quality of green open space [48], which has a significant role in urban areas [49]-[51] and also contributes to overcoming pollution [52]. The increase of built-up areas occurred as the change of agricultural and vegetated areas [4]. The large area of built-up land is one of the proofs of urban expansion within the research areas. Green open space should be considered in urban management and planning.

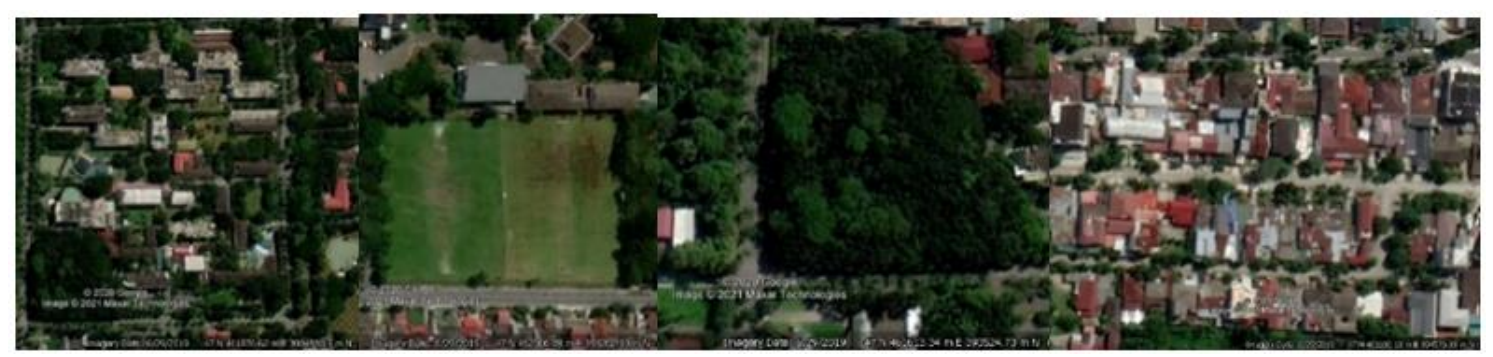

Figure 4 Visualization of some areas in Medan Baru

Figure 4 shows the existence of vegetation near the built-up land. The trees are beneficial for the environment and society (Figure 5). The improper management of the urban environment will result in the decline of environmental quality.

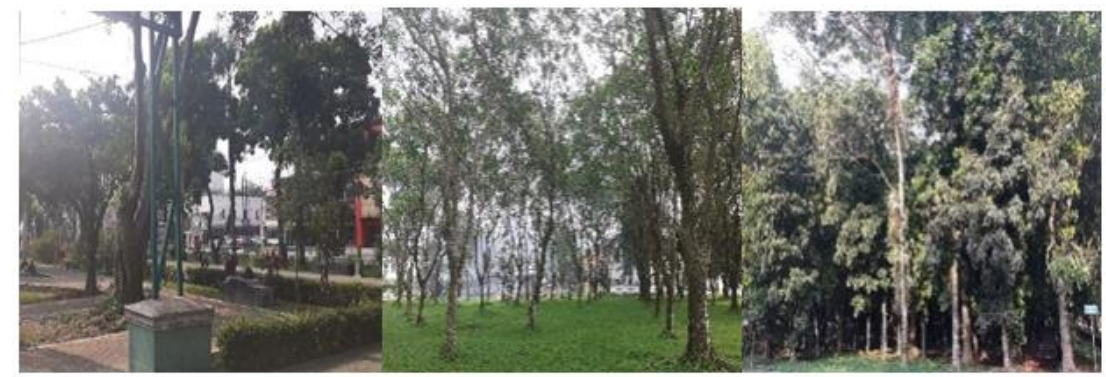

Figure 5 Trees existence in the research area

The need for built-up land increases along with the population. According to [27] stated that the rise of urban population and economic development could explain the growth of the urban landscape. Figure 6 illustrates the vegetation and land cover categories in the field.

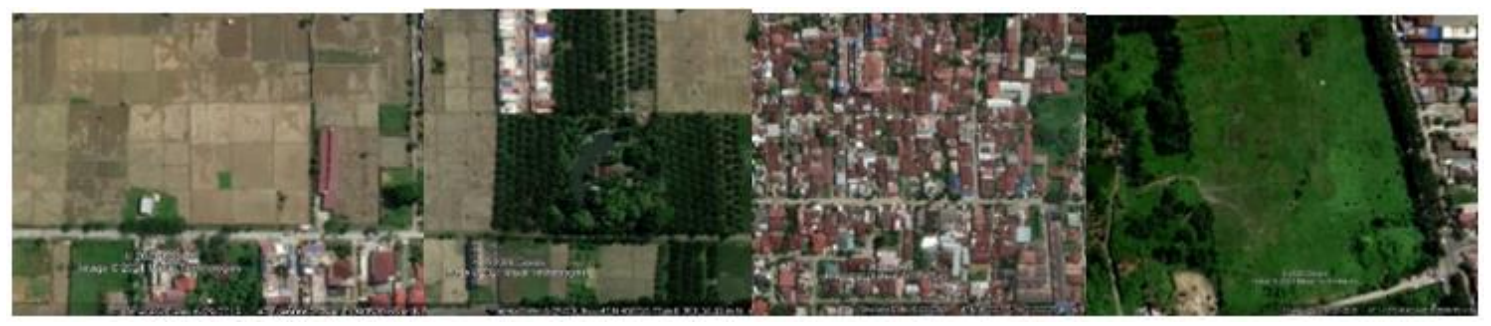

Figure 6 Visualization of some areas in Medan Selayang 
People tend to convert vegetated land to built-up land to accommodate the need for housing. The decrease of green areas could harm society. The local government has to give serious attention to vegetation existence, to maintain the quality of environment and life in urban areas. Due to the high conversion of green land to built-up land, the area is prone to flooding because of inefficient space usage that exceeds carrying capacity. The rapid growth of urbanized areas has also put a strain on precious land and water resources. It results in increased environmental stress. Addressing the numerous problems and conflicting interests that exist in urban and periurban contexts is necessary for good city planning [39]. Land cover change, as a result of urbanization, has significant consequences for society and environmental sustainability [10]. Built-up land covers the majority of the land in Medan sub-districts. There has been an increase in built-up land. It must be a shared concern among all parties so that development in this area is suitable with the environment's carrying capacity to minimize the risk of flooding and environmental harm. Land optimization through tree planting is critical for environmental quality maintenance.

Due to its combination of social and environmental characteristics, urban gardening is gaining increasing attention as a viable and socially inclusive use of urban green spaces. It is not only beneficial to the ecology but also consistent with sustainability goals [48]. Asserted by [50] that the functions of urban vegetation are strongly linked to its structure, composition, distribution, and the management criteria used. According to [48], urban gardening has grown in popularity as a financially viable and socially equitable way to utilize city green spaces. This study used Landsat image as the primary data. Landsat could be a good source for classifying the land cover in urban areas. Landsat images also used by [54] to conduct urban studies on green open space. Landsat data were analyzed to determine the effect of urban forest on the thermal environment [55]. According to [9] was also used Landsat to assess the land cover change and urban growth trend. Many studies used Landsat for land use and land cover detection and change analysis [56]-[59], [23], including in vegetation change analyse within some areas [60][63].

The maximum likelihood method is used to classify land cover classes [34]. Maximum likelihood is one of the most extensively used pixel-based and object-based image analysis techniques [33]. It is difficult to monitor three-dimensional urban densification using Landsat, notably its $30 \mathrm{~m}$ spatial resolution [57]. Statement of [3] discussed the classification error in bare soil with low vegetation density and built-up areas due to visual similarities between the two classes. Multi-spatial resolution data was also used in many studies on change analysis on land cover and land use [64]-[66].

The examination of urban expansion for effective planning and management could be accomplished through the use of an integrated strategy that incorporates remote sensing, GIS, and a matrix of urban sprawl [9]. Natural disasters and human actions are unpredictable. As a 
result, cities must act more rapidly and effectively in order to foresee and mitigate connected effects and threats [67]. Urban planning integrates and balances the diverse needs and demand of all city stakeholders [48]. City planners are more concerned with the quality of life in metropolitan areas. A multidisciplinary approach is required for assessing the quality of urban life [25].

Landsat and high-resolution Google Earth imagery are used to conduct a land use and land cover analysis [23]. High spatial and spectral resolution satellite images provide more details on urban structures [31]. There are much reason why using Landsat data remains a difficult challenge in extracting information on built-up areas. One of the reasons is the spatial-temporal expression of land cover [64]. Urban management requires high-resolution maps of land usage. However, the richness and heterogeneity of metropolitan areas complicate land use mapping [31]. Due to the range of surface materials, monitoring urban expansion with medium resolution photography continues to be difficult [44].

Additional research is required to investigate the utilization of higher-resolution remotely sensed data. The high-resolution satellite image will enhance the quality of land cover maps and allow for the precise mapping of all urban classes. High-resolution photos will aid in revealing urban trends and patterns. While urban studies encompass a broad range of topics, they all share a common goal: to solve issues and create a healthy environment for man and nature. These studies include those on smart sustainable cities [25], [68], urban ecosystem services research [69]-[70], urban resilience [71], urbanization strategy and planning [69], [72].

\section{Conclussions}

The land cover found in Medan sub-districts was a result of land use. The sub-districts were comprised of paddy fields, trees, grass, mixed plants, and shrub, as well as built-up areas. Medan baru had a built-up area of 86.0 percent. Medan selayang had a built-up area of 69.3 percent. The high percentage of built-up land could increase the risk of lower environmental quality due to the lack of vegetation. Landsat provided information on the land cover within the urban areas. Ground check data and google earth images have become primary inputs for producing an accurate land cover map. Vegetation is present in some land cover types, including paddy fields, trees, grass, mixed plant, and shrub. Urban design should be considered green open space and tree planting to maintain the quality of the environment in medan's urban regions.

\section{REFERENCES}

[1] Rivkin L, Santangelo JS, Alberti M, Aronson MF, de Keyzer CW, Diamond SE, Fortin MJ, Frazee LJ, Gorton AJ, Hendry AP, Liu Y, Losos JB, MacIvor JS, Martin RA, McDonnell MJ, Miles LS, Munshi-South J, Ness RW, Newman AE, Stothart MR, Theodorou P, Thompson KA, Verrelli BC, Whitehead A, Winchell 
KM, Johnson M T. “A roadmap for urban evolutionary ecology,” Evol. Appl. 2019. DOI: 10.1111 /eva.12734

[2] Guha S, Govil H, Monika. "An investigation on seasonal variability between LST and NDWI in an urban environment using Landsat satellite data An investigation on seasonal variability between LST and NDWI in an urban environment using Landsat satellite data," Geomatics Nat. Hazards Risk. vol. 11, no. 1, pp. 13191345. 2020. DOI: https://doi.org/10.1080/19475705.2020.1789762

[3] Dewantoro BEB, Natani PA, Islamiah Z. "Spatial Monitoring of Urban Development Direction Using Landsat 7 ETM+ and Landsat 8 OLI/TIRS in Balikpapan City, Indonesia," International $J$ of Innovative Technology and Exploring Engineering, vol. 9, no. 4, pp. 2278-3075. 2020. DOI: 10.35940/ijitee.D1893.029420

[4] Frimpong B. "Tracking Urban Expansion Using Random Forests for the Classification of Landsat Imagery (1986-2015) and Predicting Urban/Built-Up Areas for 2025: A Study of the Kumasi Metropolis, Ghana," Land vol. 10, no. 44. 2021. DOI: 10.3390/land10010044

[5] Enoguanbhor EC, Gollnow F, Nielsen JO, Lakes T, Walker BB. "Land cover change in the Abuja City-Region, Nigeria: Integrating GIS and remotely sensed data to support land use planning," Sustainability (Switzerland), vol. 11, no. 5. 2019. DOI: $10.3390 /$ su11051313

[6] Qing L, Petrosian HA, Fatholahi SN, Chapman M, Li J. "Quantifying Urban Expansion Using Landsat Images and Landscape Metrics: A Case Study of the Halton Region, Ontario," Geomatica. 2020. DOI: 10.1139/geomat-2020-0017

[7] Bhat PA, Shafiq M ul, Mir AA, Ahmed P. "Urban sprawl and its impact on landuse/land cover dynamics of Dehradun City, India," Int. J. Sustainable Built Environ, vol. 6, no. 2, pp. 513-521. 2017. DOI: 10.1016/j.ijsbe.2017.10.003

[8] Guite LTS. "Assessment of urban sprawl in Bathinda city, India," J Urban Manage, vol. 8, no. 2, pp. 195-205. 2019. DOI: 10.1016/j.jum.2018.12.002

[9] Sahana M, Hong H, Sajjad H. "Analyzing urban spatial patterns and trend of urban growth using urban sprawl matrix: A study on Kolkata urban agglomeration, India," Sci. Total Environ, pp628-629. 2018. DOI: 10.1016/j.scitotenv.2018.02.170

[10] Rimal B, Sloan S, Keshtkar H, Sharma R, Rijal S, Shrestha UB. "Patterns of historical and future urban expansion in Nepal," Remote Sens, vol. 12, no. 4. 2020. DOI: $10.3390 / \mathrm{rs} 12040628$

[11] Güneralp B, Reba M, Hales BU, Wentz EA, Seto KC. "Trends in urban land expansion, density, and land transitions from 1970 to 2010: A global synthesis," Environ. Res. Lett, vol. 15, no. 4. 2020. DOI: 10.1088/1748-9326/ab6669

[12] Alizadeh B, Hitchmough J. "A review of urban landscape adaptation to the challenge of climate change," Int. J. Clim. Change Strategies Manage, Emerald Group Publishing Ltd. 2019. DOI: 10.1108/IJCCSM-10-2017-0179

[13] Carte JG, Cavan G, Connelly A, Guy S, Handley J, Kazmierczak A. "Climate change and the city: Building capacity for urban adaptation," Progress in Planning, vol. 95, pp. 1-66. 2015. DOI: 10.1016/j.progress.2013.08.001

[14] Lenzholzer S, Carsjens GJ, Brown RD, Tavares S, Vanos J, Kim YJ, Lee K. "Urban climate awareness and urgency to adapt: An international overview," Urban Clim, vol. 33. 2020. DOI: 10.1016/j.uclim.2020.100667

[15] Masson V, Lemonsu A., Hidalgo J, Voogt J. "Urban climates and climate change," Annu. Rev. Environ. Resour., Annual Reviews Inc. 2020. DOI: 10.1146/annurevenviron-012320-083623

[16] Dardouri S, Sghaier J. "Modeling atmospheric emissions during olive husk drying and study of meteorological factors effect in the vicinity of urban areas," J. King Saud Univ. Sci, vol. 31, no. 4, pp. 635-641. 2019. DOI: 10.1016/j.jksus.2019.06.004

[17] Jorquera H, Montoya LD, Rojas NY. "Urban air pollution," In Urban Climates in Latin America, pp. 137-165. 2019. DOI: 10.1007/978-3-319-97013-4_7

[18] Qu C, Albanese S, Lima A, Hope D, Pond P, Fortelli A., ... De Vivo B. "The occurrence of OCPs, PCBs, and PAHs in the soil, air, and bulk deposition of the Naples metropolitan area, southern Italy: Implications for sources and environmental processes," Environ. Int, vol. 124, pp. 89-97. 2019. DOI: 10.1016/j.envint.2018.12.031 
[19] Shah, S.I.H., R. Nawaz, S. Ahmad, M. Arshad. "Sustainability Assessment of Modern Urban Transport and Its Role in Emission Reduction of Greenhouse Gases: A Case Study of Lahore Metro Bus. Kuwait," J. Sci., vol. 47, no. 2, pp. 67-81, 2020.

[20] Yang J, Shi B, Shi Y, Marvin, S., Zheng Y, \& Xia G. "Air pollution dispersal in high density urban areas: Research on the triadic relation of wind, air pollution, and urban form," Sustainable Cities and Soc, vol. 54. 2020. DOI: 10.1016/j.scs.2019.101941

[21] Zhou C, Li S, Wang S. "Examining the impacts of urban form on air pollution in developing countries: A case study of China's megacities," Int. J. Environ. Res. Public Health, vol. 15, no. 8. 2018a. DOI: 10.3390/ijerph15081565

[22] Yang T. "Association between perceived environmental pollution and health among urban and rural residents-a Chinese national study," BMC Public Health, vol. 20, no. 1. 2020. DOI: 10.1186/s12889-020-8204-0

[23] Gala T, Boakye L. "Spatio temporal analysis of remotely sensed Landsat time series data for monitoring 32 years of urbanization," J of Human Capital vol. 5, no. 2, pp. 85-98. 2020. DOI: 10.22034/IJHCUM.2020.02.01

[24] Wu H, Gui Z, Yang Z. "Geospatial big data for urban planning and urban management," Geo-spatial Inf. Sci vol. 23, no. 4, pp. 273-274. 2020 DOI: 10.1080/10095020.2020.1854981

[25] Garau C, Pavan VM. "Evaluating urban quality: Indicators and assessment tools for smart sustainable cities," Sustainability (Switzerland), vol. 10, no. 3. 2018. DOI: $10.3390 /$ su 10030575

[26] Zhang J, Wu H, Cai C. "Annual urban built-up change area online extraction using landsat time series data," ISPRS J. Photogramm. Remote Sens, vol. XLIII-B4-2020, 2020 XXIV ISPRS Congress. DOI: 10.5194/isprs-archives-XLIII-B4-2020-7352020

[27] Hafoud S, Boutoial K, Abdelkhalek O, Mahjoubi FZ, Kzaiber F. "Urbanization and its Impact on Land Surface Temperature Changes Using Landsat Image in Dakhla City," 2020. DOI: 10.34218/IJARET.11.6.2020.013

[28] Almazroui M, Mashat A, Assiri, ME, Butt MJ. "Application of Landsat Data for Urban Growth Monitoring in Jeddah,” Earth Syst. Environ vol. 1, no. 2. 2017. DOI: 10.1007/s41748-017-0028-4

[29] Chowdhury M, Hasan ME, Abdullah-Al-Mamun MM. "Land use/land cover change assessment of Halda watershed using remote sensing and GIS," Egypt. J. Remote Sens. Space. Sci, vol. 23, no. 1, pp. 63-75. 2020. DOI: 10.1016/j.ejrs.2018.11.003

[30] Zhang L, Tian Y, Liu Q. "A Novel Urban Composition Index Based on WaterImpervious Surface-Pervious Surface (W-I-P) Model for Urban Compositions Mapping Using Landsat Imagery," Remote Sens, vol. 13, no. 1, p 3. 2020a. DOI: https://doi.org/10.3390/rs13010003

[31] Hu T, Yang J, Li X and Gong P. "Mapping Urban Land Use by Using Landsat Imagesand Open Social Data," Remote Sens, vol. 8, no. 2, p 151. 2016. DOI: https://doi.org/10.3390/rs8020151

[32] Mauro G. "Rural-Urban Transition of Hanoi (Vietnam): Using Landsat Imagery to Map Its Recent Peri-Urbanization," International J of Geo-Information, vol. 9, no. 11, p 669. 2020. DOI: 10.3390/ijgi9110669

[33] Poursanidis D, Chrysoulakis N, Mitraka Z. "Landsat 8 vs. Landsat 5: A comparison based on urban and pen-urban land cover mapping," Int. J. Appl. Earth Obs. Geoinf, vol. 35, pp. 259-269. 2015. DOI: 10.1016/j.jag.2014.09.010

[34] Xie Z, Han Y, Sun L, Ping J. "Analysis of land cover evolution within the built-up areas of provincial capital cities in northeastern China based on nighttime light data and Landsat data," PLoS One, vol. 15, no. 10, p e0239371. 2020. DOI: 10.1371/journal.pone.0239371

[35] Alam A, Bhat MS, Maheen M. "Using Landsat satellite data for assessing the land use and land cover change in Kashmir valley," GeoJournal, vol. 85, no. 6, pp. 15291543. 2020. DOI: 10.1007/s10708-019-10037-x

[36] Magidi J, \& Ahmed F. "Assessing urban sprawl using remote sensing and landscape metrics: A case study of City of Tshwane, South Africa (1984-2015)," Egypt. J. 
Remote Sens. Space. Sci, vol. 22, no. 3, pp. 335-346. 2019. DOI: 10.1016/j.ejrs.2018.07.003

[37] Navin MS, Agilandeeswari L. "Comprehensive review on land use/land cover change classification in remote sensing," $J$ of Spectral Imaging. 2020. DOI: 10.1255/jsi.2020.a8

[38] Reis S. "Analyzing land use/land cover changes using remote sensing and GIS in Rize, North-East Turkey," Sensors, vol. 8, no. 10, pp. 6188-6202. 2008. DOI: $10.3390 / \mathrm{s} 8106188$

[39] Riad P, Graefe S, Hussein H, Buerkert A. "Landscape transformation processes in two large and two small cities in Egypt and Jordan over the last five decades using remote sensing data," Landscape Urban Plann, vol. 197. 2020. DOI: 10.1016/j.landurbplan.2020.103766

[40] Liping C, Yujun S, Saeed S. "Monitoring and predicting land use and land cover changes using remote sensing and GIS techniques-A case study of a hilly area, Jiangle, China," PLoS One, vol. 13, no. 7. 2018. DOI: 10.1371/journal.pone.0200493

[41] Alqurashi, A. F., Kumar, L., \& Sinha, P. "Urban land cover change modelling using time-series satellite images: A case study of urban growth in five cities of Saudi Arabia," Remote Sens, vol. 8, no. 10. 2016. DOI: 10.3390/rs8100838

[42] Romdhoni MF. The Use of Landsat Image and Census Data for Modelling Population Density and Urban Density in Palembang, Indonesia, 2020. DOI: 10.20885/jars.vol4.iss2.art9

[43] Goldblatt R, Stuhlmacher MF, Tellman B, Clinton N, Hanson G, Georgescu M, .. Balling RC. "Using Landsat and nighttime lights for supervised pixel-based image classification of urban land cover," Remote Sens Environ, vol. 205, pp. 253-275. 2018. DOI: $10.1016 /$ j.rse.2017.11.026

[44] Maclachlan A, Roberts G, Biggs E, Boruff B. "Subpixel land-cover classification for improved urban area estimates using landsat," Int. J. Remote Sens, vol. 38, no. 20, pp. 5763-5792. 2017. DOI: 10.1080/01431161.2017.1346403

[45] Hidayati IN, Suharyadi R. "A Comparative Study of Various Indices for Extraction Urban Impervious Surface of Landsat 8 OLI," Forum Geografi, vol. 33, no. 2, pp. 162-172. 2019. DOI: 10.23917/forgeo.v33i2.9179

[46] Shi Y, Qi Z, Liu X, Niu N, Zhang H. "Urban land use and land cover classification using multisource remote sensing images and social media data," Remote Sens, vol. 11, no. 22. 2019. DOI: 10.3390/rs11222719

[47] Twisa S, Mwabumba M, Kurian M, Buchroithner MF. "Impact of land-use/land-cover change on drinking water ecosystem services in Wami River Basin, Tanzania," Resources, vol. 9, no. 4. 2020. DOI: 10.3390/RESOURCES9040037

[48] Tappert S, Klöti T, Drilling M. "Contested urban green spaces in the compact city: The (re-)negotiation of urban gardening in Swiss cities," Landscape Urban Plann, vol. 170, pp. 69-78. 2018. DOI: 10.1016/j.landurbplan.2017.08.016

[49] Ajrina H, Kustiwan I. "From green open space to green infrastructure: The potential of green open space optimization towards sustainable cities in Bekasi City \& Regency, Indonesia," In IOP Conf. Ser.: Earth Environ. Sci., vol. 399. 2019. DOI: 10.1088/1755-1315/399/1/012130

[50] Ferrini F, Fini A, Mori J, Gori A. "Role of vegetation as a mitigating factor in the urban context," Sustainability (Switzerland). 2020. DOI: 10.3390/su12104247

[51] Noveri I, Najib K, Yusuf M. "The Analysis of Public Green Open Space Management in Jambi City," Policy \& Governance Review, vol. 4, no. 3, p 182. 2020. DOI: 10.30589/pgr.v4i3.305

[52] Selmi W, Weber C, Rivière E, Blond N, Mehdi L, \& Nowak D. "Air pollution removal by trees in public green spaces in Strasbourg city, France," Urban For. Urban Greening, vol. 17, pp. 192-201. 2016. DOI: 10.1016/j.ufug.2016.04.010

[53] Goswami M, Khire MV. "Land Use and Land Cover Change Detection for Urban Sprawl Analysis of Ahmedabad City using Multitemporal Landsat Data," International J Adv Remote Sens GIS, vol. 5, no. 1, pp. 1670-1677. 2016. DOI: 10.23953/cloud.ijarsg.51 
[54] Wikantiyoso R, Sulaksono AG, Suhartono T. "Green Open Space Area Detection Using Landsat 8 Satellite Imagery," ARTEKS: Jurnal Teknik Arsitektur, vol 6, no 1, pp. 2541-1217(e). 2021.

[55] Lee P, Park J. "An Effect of Urban Forest on Urban Thermal Environment in Seoul, South Korea, Based on Landsat Imagery Analysis," Forests, vol. 11, no. 6, p 630. 2020. DOI: 10.3390/f11060630

[56] Bagan H, Yamagata Y. "Land-cover change analysis in 50 global cities by using a combination of Landsat data and analysis of grid cells," Environ. Res. Lett, vol. 9, no. 6. 2014. DOI: 10.1088/1748-9326/9/6/064015

[57] Chen THK, Qiu C, Schmitt M, Zhu XX, Sabel CE, Prishchepov A. "Mapping horizontal and vertical urban densification in Denmark with Landsat time-series from 1985 to 2018: A semantic segmentation solution," Remote Sens Environ, vol. 251. 2020. DOI: 10.1016/j.rse.2020.112096

[58] Gbanie SP, Griffin AL, Thornton A. "Impacts on the urban environment: Land cover change trajectories and landscape fragmentation in post-war Western Area, Sierra Leone," Remote Sens, vol. 10, no. 1. 2018. DOI: 10.3390/rs10010129

[59] Ishtiaque A, Shrestha M, \& Chhetri N. "Rapid urban growth in the kathmandu valley, nepal: Monitoring land use land cover dynamics of a himalayan city with landsat imageries," Environments - MDPI, vol. 4, no. 4, pp. 1-16. 2017. DOI: 10.3390/environments4040072

[60] Zaitunah, A., Samsuri, \& Sahara, F. "Mapping and assessment of vegetation cover change and species variation in Medan, North Sumatra," Heliyon, vol. 7, no. 7. 2021. https://doi.org/10.1016/j.heliyon.2021.e07637

[61] Zaitunah A, Ras S, Samsuri. "Change vegetation density analysis of Sumatran orangutan (Pongo abelii) habitat in Bukit Lawang and Sub-district of Bahorok," IOP Conf. Ser.: Earth Environ. Sci, vol. 454, 012087. 2020. DOI: 10.1088/17551315/454/1/012087

[62] Samsuri, Zaitunah A, Siregar HI. "Analysis of vegetation density change in coastal villages of Tapanuli Tengah and Sibolga using landsat images," IOP Conf. Ser.: Earth Environ. Sci., vol. 374, 012059. 2019. Doi: 10.1088/17551315/374/1/012059

[63] Zaitunah A, Samsuri, Putri A. "Landcover change analysis of Besitang watershed, Langkat-North Sumatra," IOP Conf. Ser.: Earth Environ. Sci., vol. 1282, 012090. 2019. DOI: 10.1088/1742-6596/1282/1/012090

[64] Toure SI, Stow DA, Shih H. chien, Weeks J, Lopez-Carr D. "Land cover and land use change analysis using multi-spatial resolution data and object-based image analysis," Remote Sens. Environ, vol. 210, pp. 259-268. 2018. DOI: 10.1016/j.rse.2018.03.023

[65] Zhou T, Li Z, Pan J. "Multi-feature classification of multi-sensor satellite imagery based on dual-polarimetric sentinel-1A, landsat-8 OLI, and hyperion images for urban land-cover classification," Sensors (Switzerland), vol. 18, no. 2. 2018. DOI: $10.3390 / \mathrm{s} 18020373$

[66] Mugiraneza T, Nascetti A, Ban Y. "Continuous monitoring of urban land cover change trajectories with landsat time series and landtrendr-google earth engine cloud computing," Remote Sens, vol. 12, no. 18. 2020. DOI: 10.3390/RS12182883

[67] Ribeiro PJG, Pena Jardim Gonçalves LA. "Urban resilience: A conceptual framework," Sustainable Cities Soc. 2019. DOI: 10.1016/j.scs.2019.101625

[68] Tang HT, \& Lee YM. "The making of sustainable urban development: A synthesis framework," Sustainability (Switzerland), vol. 8, no. 5, pp. 1-28. 2016. DOI: $10.3390 /$ su8050492

[69] Han L, Zhou W, Li W, \& Qian Y. "Urbanization strategy and environmental changes: An insight with relationship between population change and fine particulate pollution," Sci. Total Environ, vol. 642, pp. 789-799. 2018. DOI: 10.1016/j.scitotenv.2018.06.094

[70] Kremer P, Hamstead Z., Haase D, McPhearson T, Frantzeskaki N, Andersson E, ... Elmqvist T. "Key insights for the future of urban ecosystem services research," Ecol. Soc, vol. 21, no. 2. 2016. DOI: 10.5751/ES-08445-210229 
[71] Bush J, Doyon A. "Building urban resilience with nature-based solutions: How can urban planning contribute?," Cities, vol. 95. 2019. DOI: 10.1016/j.cities.2019.102483

[72] Guzal-Dec D, Zbucki Ł, Kuś A. "Good governance in strategic planning of local development in rural and urban-rural gminas of the eastern peripheral voivodeships of Poland. Bulletin of Geography," Socio-economic Series, vol. 50, no. 50, pp. 101112. 2020. DOI: http://dx.doi.org/10.1515/19924 